\title{
EFEKTIFITAS TUBEX SEBAGAI METODE DIAGNOSIS CEPAT DEMAM TIFOID
}

\author{
$I_{\text {Gede Krisna Yoga Pratama }}^{1}$, A.A. Wiradewi Lestari ${ }^{2}$ \\ Program Studi Pendidikan Dokter, Fakultas Kedokteran Universitas Udayana ${ }^{1}$ \\ Bagian Patologi Klinik Fakultas Kedokteran Universitas Udayana ${ }^{2}$
}

(krisnayogaa@gmail.com)

\begin{abstract}
Abstrak
Demam tifoid merupakan penyakit sistemik yang disebabkan oleh bakteri Salmonella enterica serotype Typhi. Berbagai upaya pengembangan metode diagnostik dilakukan untuk mendapatkan cara yang cepat, tidak susah, dan murah. Salah satu metode terkini yang mampu mendiagnosis secara cepat dan memiliki sensitivitas dan spesifisitas yang memuaskan adalah tes TUBEX. Test TUBEX merupakan tes serologi yang mendeteksi immunoglobulin M dalam melawan antigen spesifik 09 Salmonella typhi. Tes ini menggunakan metode aglutinasi kompetitif semi kuantitatif dengan partikel berwarna sebagai tolak ukur penegakan diagnosis.
\end{abstract}

Kata kunci : demam tifoid, metode diagnosis, tes TUBEX, Salmonella typhi

\begin{abstract}
Typhoid fever is caused by Salmonella typhii or Salmonella paratyhpii. Many diagnostic methods have been developed to find the fastest, easiest, and cheapest way to achieve the highest sensitivity and specificity. A method that can diagnose fast and good sensitivity and specificity is TUBEX test. TUBEX test is a serologic test that detects immunoglobulin $\mathrm{M}$ against specific antigen 09 S.typhii. This test use semi-quantitative agglutination competitive method with colored particle.
\end{abstract}

Key point : typhoid fever, diagnosis methods, TUBEX test, Salmonella typhi

\section{Pendahuluan}

Demam tifoid menjadi permasalahan kesehatan di dunia. Tercatat banyak kasus pada negara tropis dan juga negara subtropis, terutama negara berkembang. Penyebaran penyakit ini berkaitan dengan pemukiman padat dan kebersihan lingkungan.

Menurut data WHO 2003, tercatat 17 juta kasus di dunia dan 600.000 kasus kematian tiap tahun. Insiden 1307/100.000 kasus per tahun pada anak $<5$ tahun dan 769,3/100.000 kasus per tahun untuk populasi $>5$ tahun di regional Asia Timur dan Tenggara pada tahun 2010 dengan angka mortalitas 0,3/100.000 kasus setiap tahunnya. Sementara itu di Asia Tenggara, khususnya Indonesia, masih tergolong insiden tinggi penyakit tifoid..$^{1,2,3}$

Berbagai upaya pengembangan metode diagnostik demam tifoid guna menemukan cara yang tepat dan cepat. Penentuan diagnosis yang tepat merupakan masalah serius untuk membedakannya dari sindrom febril lainnya seperti demam dengue. Penegakan diagnosis secara dini sangat penting dalam membantu usaha penatalaksanaan penderita secara menyeluruh dan usaha kontrol penyebaran penyakit melalui identifikasi karier. Pemberian terapi yang cepat dan sesuai akan sangat membantu pasien dalam perawatan dan penyembuhan. Salah satu metode terkini yang mampu mendiagnosis secara cepat dan memiliki sensitivitas dan spesifisitas yang memuaskan adalah melalui uji semikuantitatif.

Test TUBEX merupakan tes serologi yang mendeteksi immunoglobulin $\mathrm{M}$ dalam melawan antigen spesifik 09 Salmonella typhi. ${ }^{4}$ Tes ini menggunakan metode aglutinasi kompetitif semi kuantitatif dengan partikel berwarna sebagai tolak ukur penegakan diagnosis.

\section{Demam Tifoid}

Saat ini, tifoid merupakan penyakit yang banyak terjadi di berbagai negara. Penyebabnya adalah kuman Salmonella enterica serotype Typhii (S.typhii). ${ }^{5}$ Bakteri ini tergolong bakteri gram negatif dengan bentuk batang, , tidak berspora, memiliki kapsul dan berflagella (rambut getar). Penyakit ini menjangkit manusia melalui oral dari makanan yang terjangkit.

Presentasi klinis demam tifoid mulai dari ringan (demam tinggi, denyut jantung lemah, sakit kepala, malaise, myalgia) hingga berat (ketidaknyamanan perut dan komplikasi pada hati dan limfa). ${ }^{6}$ bermanifestasi hingga 10-14 hari. Pada minggu pertama timbul gejala demam, pusing, nyeri kepala, mual, muntah, nyeri kepala, rasa tidak nyaman pada perut, obstipasi atau 


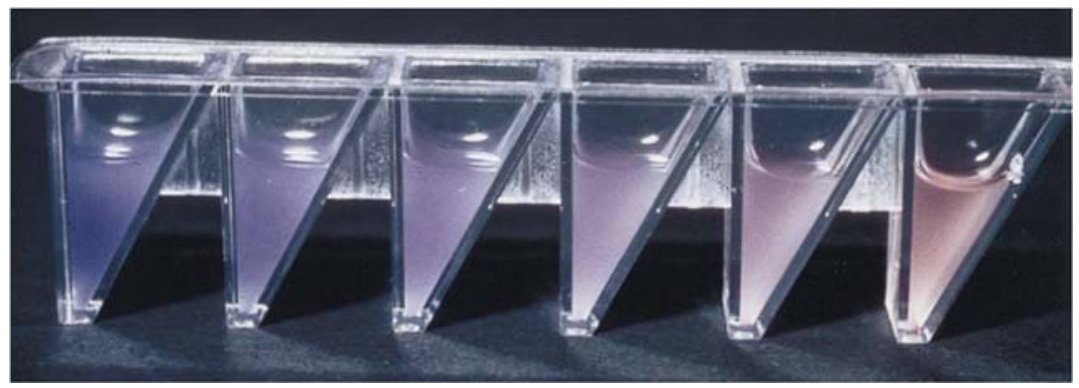

Gambar 1. derajat perubahan warna pada tes. ${ }^{8}$

diare, batuk, serta epitaksis. Pada minggu kedua timbul gejala demam yang lebih berat, meningkat perlahan terutama pada sore dan malam hari, bradikardi, lidah berselaput, pembesaran hati dan limfa, serta gangguan mental (delirium, stupor, somnolen, atau psikosis). ${ }^{7}$

Gejala penyakit ringan dapat menjadi berat sehingga menimbulkan komplikasi. Komplikasi yang terjadi terutama pada bagian intestinal berupa pendarahan, perforasi usus, paralitik ileus, dan pancreatitis, tetapi dapat menyebar ekstra-intestinal antara lain gangguan kardiovaskuler, anemia hemolitik, hepatitis, gangguan ginjal, hingga komplikasi neuropsikiatrik/ tifoid toksik. ${ }^{7}$

Pemeriksaan laboratorium untuk penegakan diagnosis dibagi menjadi empat, yaitu: (1) pemeriksaan isolasi bakteriologis dan biakan kuman (2) darah tepi; (3) pemeriksaan molekuler kuman dan (4) uji serologis

Penatalaksanaan demam tifoid meliputi istirahat total (tirah baring), diet dan terapi-terapi penunjang, serta perawatan medis dengan antibiotik untuk proses penyembuhan dan menghindari munculnya komplikasi. Pakaian, lingkungan sekitar pasien dan kelengkapan pasien mutlak diawasi kebersihannya. Antibiotik yang diberikan antara lain

Pengerjaan tes diawali dengan mencampur serum $(25 \mu \mathrm{L})$ dan $25 \mu \mathrm{L}$ reagen A pada tabung. Lakukan hal serupa pada tabung-tabung lainnya. Tutup tabung reaksi dengan strip lalu ubah posisi tabung yang vertikal ke arah horizontal. Tabung digoyang-goyangkan ke depan dan ke belakang. Tabung lalu didiamkan pada rak tabung yang mengandung magnet, diputar selama 2 menit dengan kecepatan $250 \mathrm{rpm}^{7}$

Diamkan untuk proses pengendapan selama 5 menit. Partikel magnetik yang dilapisi antigen (lipopolisakarida Salmonella typhi) akan berikatan dengan partikel lateks biru yang dibungkus antibodi antiLPS S.thyphi. Ketika partikel bermagnetik mengendap di bagian bawah tube, partikel lateks biru juga akan turun ke bawah. Hal ini akan meninggalkan supernatant kloramfenikol 4x500 mg per hari secara per oral atau pun intra vena sampai dengan 7 hari bebas panas. ${ }^{7}$

\section{Tes TUBEX}

Tes TUBEX merupakan tes aglutinasi kompetitif semi kuantitatif sederhana yang cepat ( lebih kurang 2 menit). Sensitivitasnya mampu ditingkatkan melalui penggunaan partikel berwarna, sedangkan spesifisitasnya ditingkatkan dengan penggunaan antigen 09, antigen ini spesifik dan khas pada Salmonella serogrup D. Tes ini mendeteksi adanya antibodi IgM. Respon terhadap antigen 09 berlangsung cepat karena antigen 09 bersifat imunodominan yang mampu merangsang respon imun $\mathrm{Hal}$ ini menguntungkan, sebab deteksi anti-09 dapat dilakukan lebih cepat, yaitu pada hari ke 4-5 ( infeksi primer) dan hari ke 2-3 ( infeksi sekunder $)^{7}$

Melakukan pemeriksaan memerlukan alat dan beberapa reagen, yaitu: tabung berbentuk $V$, reagen $A$ yang berisi partikel bermagnetik yang telah diselimuti antigen S.typhi 09, dan reagen B yang berisi partikel lateks berwarna biru yang diselimuti antibodi spesifik antigen 09. ${ }^{7}$

bening. Penambahan partikel lateks merah pada reaksi tersebut akan menyebabkan supernatant berwarna merah dan akan lebih mudah terlihat dibandingkan tidak berwarna. Bila terdapat antibodi anti-09 pada sampel penderita, antibodi tersebut akan menghambat ikatan partikel biru dengan partikel bermagnetik, sehingga supernatant tetap berwarna biru. ${ }^{8}$

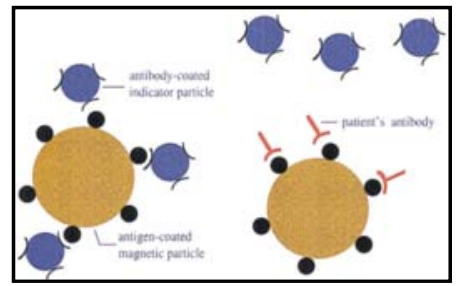

Gambar 2. hasil negatif (kiri), hasil positif (kanan) ${ }^{8}$ 


\begin{tabular}{|l|l|l|}
\hline Nilai & Interpretasi & Penjelasan \\
\hline$<2$ & $\begin{array}{l}\text { negatif } \\
\text { borderline }\end{array}$ & - \\
& $\begin{array}{l}\text { Pengukuran tidak dapat disimpulkan, perlu } \\
\text { diulangi setelah beberapa hari }\end{array}$ \\
$4-5$ & $\begin{array}{l}\text { positif } \\
\text { positif }\end{array}$ & $\begin{array}{l}\text { Adanya infeksi tifoid akut } \\
\text { Indikasi kuat adanya infeksi tifoid }\end{array}$ \\
\hline
\end{tabular}

Tabel 1. Interpretasi warna tes TUBEX. ${ }^{7}$

Hasil pemeriksaan ditentukan dengan pembacaan warna pada hasil akhir reaksi lalu kemudian dicocokkan dengan skor yang tertera pada color scale.

Skor <2 menunjukkan hasil negatif, skor 3 dikategorikan borderline (pengukuran tidak dapat disimpulkan, perlu diulangi beberapa hari kemudian), skor 4-5 menunjukkan infeksi tifoid aktif, dan skor $>6$ merupakan indikasi kuat adanya infeksi tifoid. ${ }^{7}$

Tes TUBEX yang bernilai positif disertai tanda gejala demam tifoid, merupakan indikasi sangat kuat adanya demam tifoid.

Sonja dkk, menggunakan 3 tes uji serologi sebagai eksperimen. Didapatkan bahwa tes TUBEX memiliki sensitifitas dan spesifisitas tinggi ( $78 \%$ dan $89 \%)$ jika dibandingkan tes carik celup Multi-Test Dip-STicks (89 dan 53\%), TyphiDot (79 dan 89\%), serta Widal Test ( 64 dan 76\%). ThypiDot dan tes TUBEX menunjukkan hasil yang tidak berbeda jauh, namun jika dipertimbangkan dari segi biaya dan teknik pemeriksaannya, tes TUBEX lebih unggul dengan biaya relatif lebih murah dan prosedur yang sederhana. ${ }^{9}$

Berdasarkan penelitian Kawano dkk, dari 177 kasus pasien febris di Filipina, didapatkan hasil dengan sensitifitas (tertinggi sampai terendah) adalah Mega-IgG 96,0\%, TUBEX 94,7\%, Mega-IgM 90,7\%, Typhidot-IgG 73,3\%, SD Bioline-lgG 70,7\%, SD Bioline-IgM 69,0\%, Typhidot-IgM 54,7\%. Sedangkan spesifisitas, tes TUBEX merupakan yang tertinggi. Hasil tes dari yang tertinggi sampai terendah adalah TUBEX 80,4\%, SD Bioline-IgM 79,3\%, SD Bioline-IgG 76,1\%, Thyphidot-IgM 64,7\%, Mega-IgM 49,0\%, Typhidot-IgG 46,1\%, dan Mega-IgG $39,2 \%$. Secara keseluruhan, tes TUBEX memiliki kualitas yang lebih baik dengan sensitifitas $94,7 \%$ dan spesifisitas 80,4\% dibandingkan tes serologi Typhidot, SD Bioline Typhoid dan Mega Salmonella. ${ }^{10}$

Tes TUBEX dapat dijadikan sebagai pemeriksaan ideal dan digunakan secara rutin karena cepat, dan mudah. Kelebihan tes TUBEX dibandingkan tes lain diantaranya adalah mendeteksi infeksi akut Salmonella typhi secara dini karena antibodi IgM muncul pada hari ke-3 terjadinya demam, mempunyai sensitivitas yang tinggi terhadap kuman Salmonella, membutuhkan sampel darah yang sedikit, serta hasil yang dapat diperoleh secara cepat.

Tes TUBEX merupakan prosedur yang tercepat memberikan hasil. Berdasarkan urutannya, tes TUBEX ( 5 menit), SD Bioline (15-30 menit), Mega Salmonella (2,53,0 jam), dan Typhidot memerlukan waktu 2,5 jam. ${ }^{10}$

Tes TUBEX ini tidak dapat digunakan pada spesimen yang sangat hemolitik atau ikterik. Selain itu, kadang-kadang sulit untuk menginterpretasikan hasil positif lemah. ${ }^{1}$

\section{Simpulan}

Demam tifoid adalah penyakit sistemik yang disebabkan oleh bakteri Salmonella enterica serotype Typhi. Penyakit ini menjangkit manusia melalui oral dari makanan yang terjangkit.

Presentasi klinis demam tifoid bervariasi dari penyakit ringan dengan tingkat rendah demam, sakit kepala, bradikardi, hingga timbulnya gambaran klinis yang berat dengan ketidaknyamanan perut, pembesaran hati, limfa dan beberapa komplikasi.

Tes TUBEX adalah tes semikuantitatif kolorimetrik yang cepat ( lebih kurang 2 menit). Sensitivitasnya mampu ditingkatkan dengan penggunaan partikel berwarna, sedangkan spesifisitasnya ditingkatkan dengan penggunaan antigen 09, antigen ini spesifik dan khas untuk Salmonella serogrup D. Tes ini mendeteksi adanya antibodi IgM.

Kelebihan-kelebihan tes TUBEX dibandingkan tes lain antara lain: mendeteksi infeksi akut Salmonella typhi secara dini karena antibodi IgM muncul pada hari ke-3 terjadinya demam,, mempunyai sensitivitas yang tinggi terhadap kuman Salmonella, diperlukan sedikit sample darah, dan hasil dapat diperoleh lebih cepat. Namun, ada masalah ketika spesimen yang sangat 
hemolitik atau ikterik. Selain itu, kadang-kadang sulit untuk menginterpretasikan hasil dalam batas positif.

Secara keseluruhan, tes TUBEX memiliki sensitifitas dan spesifisitas yang lebih baik dengan dibandingkan tes serologi lain seperti Typhidot, SD Bioline Typhoid dan Mega Salmonella.

\section{Daftar Pustaka}

1. Chan RCY, Leung DTM, Lim PL, Ling TKW, Tam FCH, Wong KT. 2008. "The TUBEX Test Detect not Only Typhoid-Specific Antibodies but Also Soluble Antigens and Whole Bacteria". Journal of Medical Microbiology. 57. 316-23

2. Black RE, Buckle GC, Walker CLF. 2012. "Typhoid Fever and Paratyphoid Fever: Systemic review to Estimate Global Morbidity and Mortality for 2010". Journal of Global Health. 2(1). 1-9.

3. Crump JA, Luby SP, Mintz ED. 2004. "The Global Burden of Typhoid Fever". Bulletin of the World Health Organization. 82(5). 346-53.

4. Ame SM, Amos B, Ley B, Mtove GM, Thriemer K, Seidlein LV, et al. 2011. "Assessment and Comparative Analysis of A Rapid Diagnosis test $\left(\right.$ Tubex $^{\circledR}$ ) for the Diagnosis of Typhoid fever Among Hospitalized Children in Rural Tanzania". BMC Infectious Diseases. 11(147). 1-6.

5. Bhan S, Kumar N, Mitra R, Trigunayat A. 2010. “New Advances in the Rapid Diagnosis of Typhoid Fever". African Journal of Microbiology Research. 49(16): 1676-1677.

6. WHO. 2003. Department of Vaccines and Biologicals. Background document: The diagnosis, treatment and prevention of typhoid fever, Geneva.

7. Widodo D, 2009. "Demam Tifoid". In Alwi I, Setiati S, Setiyohadi B, Simadibrata M, Sudoyo AW (Ed.). Buku Ajar Ilmu Penyakit Dalam Edisi Ke-5 (pp. 2797-806). InternaPublishing, Jakarta.

8. Cheong YM, Jegathesan M, Lim PL, Tam FCH. 1998. "One-Step 2-Minute Test To Detect Typhoid-Specific Antibodies Based on Particle Separation in Tubes". J.Clin. Microbiol. 36(8). 2271-8.

9. Bibb W, Minh NT, Olsen SJ, Pruckler J, Thanh NTM, Trinh TM, et al. 2004. "Evaluation of Rapid Diagnostic Tests for Typhoid Fever". Journal of Clinical Microbiology. 42(5). 1885-9.

10. Agdamag DMA, Kawano RL, Leano SA. 2007. "Comparison of Serological Test Kits for Diagnosis of Typhoid Fever in the Philippines". J. Clin. Microbiol. 45(10). 246-47. 